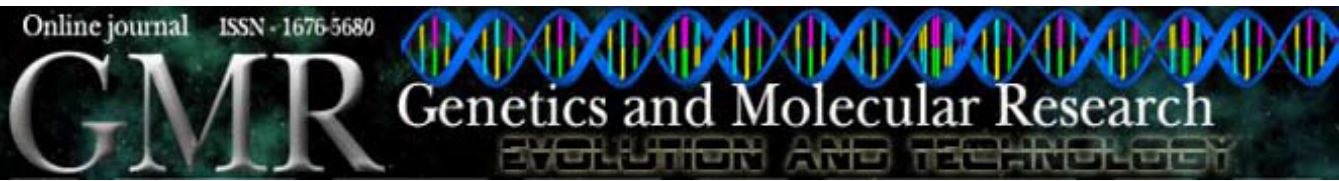

\title{
Antioxidant effect of haptoglobin phenotypes against DNA damage induced by hydrogen peroxide in human leukocytes
}

\author{
L.R.S. Moreira, A.L. Miranda-Vilela, I.C.R. Silva, A.K. Akimoto, \\ M.N. Klautau-Guimarães and C.K. Grisolia \\ Departamento de Genética e Morfologia, \\ Instituto de Ciências Biológicas, Universidade de Brasília, Brasília, DF, Brasil \\ Corresponding author: L.R.S. Moreira \\ E-mail: leonorarsm@gmail.com
}

Genet. Mol. Res. 8 (1): 284-290 (2009)

Received December 9, 2008

Accepted January 15, 2009

Published March 10, 2009

\begin{abstract}
Human haptoglobin is classified into three major phenotypes: Hp1-1, Hp2-1 and Hp2-2; there are two autosomal alleles $H p^{* 1}$ and $H p^{* 2}$, and the $H p^{* I}$ allele has two subtypes, $H p^{* I F}$ and $H p^{* I S}$. Haptoglobin acts as an antioxidant, preventing hemoglobin-driven oxidative damage. We used the comet assay to examine oxidative damage to DNA induced by hydrogen peroxide in human leukocytes; we also looked for differences in the antioxidant capacity of haptoglobin subtypes. Haptoglobin genotypes were determined through allele-specific polymerase chain reaction, visualized on a polyacrylamide gel. The Hp1-1 genotype had the least DNA damage; this indicates that $H p$ alleles differ in their protective effects against oxidative damage. Among $H p^{* I}$ alleles, $H p^{* I F}$ was the most protective.
\end{abstract}

Key words: Haptoglobin polymorphism; Antioxidant; Hydrogen peroxide; Comet assay 


\section{INTRODUCTION}

Haptoglobin $(\mathrm{Hp})$ is a serum glycoprotein with the ability to bind free hemoglobin $(\mathrm{Hb})$ in the plasma and block $\mathrm{Hb}$-induced oxidative damage. In humans, there are two codominant alleles for $\mathrm{Hp}$, denoted $H p^{* I}$ and $H p^{* 2}$, located on chromosome 16q22.1, and there are three different possible phenotypes: Hp1-1, Hp2-1 and Hp2-2 (Smithies, 1955; Smithies and Walker, 1956). On starch gels with urea, the $H p^{* I}$ allele revealed two subtypes, $H p^{* I S}$ and $H p^{* I F}$ (Smithies et al., 1962). Haptoglobin polymorphism is associated with the prevalence and clinical evolution of many inflammatory diseases, including infections, atherosclerosis and autoimmune disorders (Langlois and Delanghe, 1996). Such associations can be explained by functional differences between the subtypes in the binding of $\mathrm{Hb}$ and the rate of $\mathrm{Hb}$ clearance from the plasma (Langlois and Delanghe, 1996; Wassell, 2000; Carter and Worwood, 2007). However, these functional differences have never been associated with the subtypes $H p^{* I F}$ and $H p^{* I S}$.

The serum levels of $\mathrm{Hp}$ are phenotype-dependent; various functional properties of Hp phenotypes have been described as a direct consequence of hemoglobin-binding and protection against oxidative stress. The antioxidant role of haptoglobin to prevent possible oxidative damage induced by free hemoglobin has been widely studied (Langlois and Delanghe, 1996; Wassel, 2000; Sadrzadeh and Bozorgmehr, 2004; Guéye et al., 2006).

It is well known that DNA suffers constant oxidative damage from free radicals generated by reactive oxygen species (ROS). Normal cellular metabolism is well known to be the source of endogenous ROS; these cellular processes account for the background levels of oxidative DNA damage detected in normal tissue (Collins et al., 1995). Singlecell gel electrophoresis (comet assay) provides a very sensitive method for detecting DNA damage at the single cell level (Collins et al., 1995; Brendler-Schwaab et al., 2005). The alkaline comet assay is increasingly used in genotoxicity testing in vitro and is also becoming an important tool for evaluating the genotoxic potential of compounds in vivo (Hartmann et al., 2003; Brendler-Schwaab et al., 2005). Among the advantages of the comet assay are its sensitivity for detecting low levels of DNA damage, the need for only a small number of cells per sample, and its applicability to any kind of eukaryotic organism and cell type (Silva et al., 2000; Brendler-Schwaab et al., 2005).

We evaluated the genetic polymorphism of $\mathrm{Hp}$ and its ability to protect DNA in human leukocytes against oxidative damage induced by exposure to hydrogen peroxide.

\section{MATERIAL AND METHODS}

\section{Criteria for selection of donors, description and processing of samples}

Peripheral blood samples and clinical data of 61 healthy donors (32 females and 29 males), with ages varying between 17 and 31 years old, were collected from students of the Universidade de Brasília (UnB). Written informed consent was obtained from all participants in the study. This research project was approved by the Ethics Committee of the Universidade de Brasília, number 0.001668/2005-18, following the protocol recommended by the Helsinki Declaration. 


\section{Single-cell gel electrophoresis}

The comet assay (alkali method) was carried out according to Singh et al. (1988), with a few modifications. Microscope slides were dipped briefly on $1.5 \%$ hot $\left(60^{\circ} \mathrm{C}\right)$ normal melting agarose prepared in phosphate-buffered saline. The slides were dried overnight at room temperature and then stored at $4^{\circ} \mathrm{C}$ until use. Subsequently, freshly collected EDTA-treated peripheral blood of each sample $(20 \mu \mathrm{L})$ was suspended on $120 \mu \mathrm{L} 0.5 \%$ low melting point agarose in phosphate-buffered saline (Gibco BRL) at $37^{\circ} \mathrm{C}$ and pipetted onto eight microscope slides pre-coated with a layer of normal melting point agarose. This mixture was allowed to set at $4^{\circ} \mathrm{C}$ for $10 \mathrm{~min}$. Treatment was made with $150 \mu \mathrm{L}$ hydrogen peroxide $\left(\mathrm{H}_{2} \mathrm{O}_{2}\right)$ at concentrations of $250 \mu \mathrm{M}, 1.0$ and $2.0 \mathrm{mM}$, for $5 \mathrm{~min}$ at $4^{\circ} \mathrm{C}$, using two slides for each treatment. The control slides were prepared under the same conditions, but without the $\mathrm{H}_{2} \mathrm{O}_{2}$. The slides were immersed into a freshly prepared cold $\left(4^{\circ} \mathrm{C}\right)$ lysis solution $\left(2.5 \mathrm{M} \mathrm{NaCl}, 100 \mathrm{mM} \mathrm{Na}{ }_{2} \mathrm{EDTA}, 10\right.$ mM Tris, $\mathrm{NaOH}, \mathrm{pH} 10.0-10.5,1 \%$ lauroyl sarcosine, and $1 \%$ Triton $\mathrm{X}-100$ and $10 \%$ dimethyl sulfoxide were added immediately before use) at $4^{\circ} \mathrm{C}$ for $1 \mathrm{~h}$. After lysis, the slides were placed in an electrophoretic tank in $300 \mathrm{mM} \mathrm{NaOH}$ and $1 \mathrm{mM}$ EDTA, $\mathrm{pH}>13.0$, for $30 \mathrm{~min}$. Subsequently, electrophoresis run at $25 \mathrm{~V}$ and $350 \mathrm{~mA}$ for $40 \mathrm{~min}$. Soon after neutralization $(3 \times 5 \mathrm{~min}$ in $0.4 \mathrm{M}$ Tris, $\mathrm{pH} 7.5$, at $4^{\circ} \mathrm{C}$ ), the slides were stained with ethidium-bromide at $20 \mu \mathrm{g} / \mathrm{mL}$, fixed with $100 \%$ ethanol for $5 \mathrm{~min}$ and analyzed with a Zeiss Axioskop 2 fluorescence microscope (filter $510-560 \mathrm{~nm}$, barrier filter $590 \mathrm{~nm}$ ) with a total magnification of 400X. All slides were duplicated. One hundred comets on each slide were scored visually as belonging to one of the five classes proposed by Collins et al. (1995), and the number of comets in each category was counted and the DNA damage was calculated according to Jaloszynski et al. (1997).

\section{Determination of haptoglobin genotypes}

Genomic DNA was isolated from peripheral blood samples and collected in Vacutainer tubes containing EDTA using a purification kit GFX (GE Healthcare, Buckinghamshire, England). The samples were stored at $-20^{\circ} \mathrm{C}$ until analysis. $H p^{* l}$ genotypes were determined by allele-specific polymerase chain reaction (PCR), as described by Yano et al. (1998). PCR primer pairs used for genotyping and identification of alleles $H p^{* I F}, H p^{* I S}$ and $H p^{* 2}$ were produced with independent systems, using three PCRs for each DNA sample. The PCR products were visualized by electrophoresis on $6 \%$ non-denaturing polyacrylamide gels stained with silver nitrate. The accuracy of haptoglobin genotyping was tested by comparison with the results of haptoglobin protein phenotyping performed with the same plasma samples. There were no discrepancies between genotyping and phenotyping using these two methodologies.

\section{Statistical analysis}

Allelic and phenotypic frequencies were calculated by gene counting. Hardy-Weinberg equilibrium was evaluated by means of the chi-square test. Values of $\mathrm{P}>0.05$ were considered to be in Hardy-Weinberg equilibrium.

In order check for all possible differences among the groups, we used ANOVA from MINITAB ${ }^{\circledR}$ release 14.20. The continuous variables were tested for normal distributions with Shapiro-Wilk. There was heterogeneous variability, so a Box-Cox transformation was used so 
that ANOVA could be run. The difference between DNA damage means was analyzed by the Tukey test or by the Fisher test $(\alpha=0.05)$.

\section{RESULTS}

The frequencies of haptoglobin phenotypes and genotypes (Table 1) were in HardyWeinberg equilibrium $(\mathrm{P}>0.05)$. The allele frequency for $H p^{* I F}$ was $13.7 \%$; for $H p^{* I S}$ it was $27.4 \%$, and for $H p^{* 2}$ it was $58.9 \%$.

Table 1. Frequencies of haptoglobin phenotypes and genotypes.
\begin{tabular}{llcc}
\hline Phenotypes & Genotypes & No. of individuals & Genotype frequencies \\
\hline $1-1$ & $H p^{* / S} H p^{* I S}$ & 4 & 0.065 \\
& $H p^{* / S} H p^{* I F}$ & 2 & 0.032 \\
& $H p^{* I F} H p^{* I F}$ & 3 & 0.048 \\
\hline $2-1$ & $H p^{* 2} H p^{* I S}$ & 24 & 0.387 \\
& $H p^{* 2} H p^{* I F}$ & 9 & 0.145 \\
\hline $2-2$ & $H p^{* 2} H p^{* 2}$ & 20 & 0.323 \\
\hline
\end{tabular}

Allelic and genotypic frequencies were calculated by gene counting. Hardy-Weinberg equilibrium was evaluated by means of the chi-square test.

There was a positive correlation between $\mathrm{H}_{2} \mathrm{O}_{2}$ concentrations and DNA damage levels (Table 2). The three $\mathrm{H}_{2} \mathrm{O}_{2}$-treated groups were significantly more damaged than the controls $\left(\mathrm{P}=0.001\right.$, ANOVA). The leukocytes treated with $250 \mu \mathrm{M} \mathrm{H}_{2} \mathrm{O}_{2}$ were also significantly less damaged than those treated with 1.0 and $2.0 \mathrm{mM}(\mathrm{P}<0.05$, Tukey test $)$.

\begin{tabular}{|c|c|c|c|c|c|c|c|c|c|}
\hline Phenotypes & $\begin{array}{c}\mu \text { (score) } \pm \mathrm{SE} \\
\text { Control}^{*}\end{array}$ & $\begin{array}{c}\mu(\text { score }) \pm \mathrm{SE} \\
\mathrm{H}_{2} \mathrm{O}_{2}(250 \mu \mathrm{M})^{* *}\end{array}$ & $\begin{array}{l}\mu(\text { score }) \pm \mathrm{SE} \\
\mathrm{H}_{2} \mathrm{O}_{2}(1 \mathrm{mM})^{* *}\end{array}$ & $\begin{array}{c}\mu(\text { score }) \pm \mathrm{SE} \\
\mathrm{H}_{2} \mathrm{O}_{2}(2 \mathrm{mM})^{* *}\end{array}$ & Genotypes & $\begin{array}{c}\mu \text { (score) } \pm \mathrm{SE} \\
\text { Control* }^{*}\end{array}$ & $\begin{array}{c}\mu(\text { score }) \pm \mathrm{SE} \\
\mathrm{H}_{2} \mathrm{O}_{2}(250 \mu \mathrm{M})^{* *}\end{array}$ & $\begin{array}{c}\mu(\text { score }) \pm \mathrm{SE} \\
\mathrm{H}_{2} \mathrm{O}_{2}(1 \mathrm{mM})^{* *}\end{array}$ & $\begin{array}{c}\mu(\text { score }) \pm \mathrm{SE} \\
\mathrm{H}_{2} \mathrm{O}_{2}(2 \mathrm{mM})^{* *}\end{array}$ \\
\hline \multirow[t]{3}{*}{$1-1$} & $36.13 \pm 7.05^{\mathrm{a}}$ & $120.55 \pm 26.96^{\mathrm{a}}$ & $160.39 \pm 37.25^{\mathrm{a}}$ & $241.44 \pm 44.20^{\mathrm{a}}$ & $H p^{\star / S} H p^{* I S}$ & $46.63 \pm 14.70$ & $110.63 \pm 45.84$ & $147.25 \pm 66.93$ & $202.25 \pm 81.33$ \\
\hline & & & & & $H p^{* / S} H p^{* / F}$ & $26.64 \pm 1.36$ & $193.70 \pm 75.31$ & $253.15 \pm 60.85$ & $378.50 \pm 3.50$ \\
\hline & & & & & $H p^{\star I F} H p^{\star I F}$ & $28.46 \pm 5.45^{\mathrm{c}}$ & $85.00 \pm 12.22$ & $116.06 \pm 49.93$ & $202.33 \pm 46.49$ \\
\hline \multirow[t]{2}{*}{$2-1$} & $81.23 \pm 11.65^{\mathrm{b}}$ & $136.81 \pm 14.03^{b}$ & $204.31 \pm 17.46^{b}$ & $242.42 \pm 18.24^{b}$ & $H p^{* 2} H p^{* I S}$ & $91.73 \pm 14.91$ & $151.49 \pm 17.09$ & $221.06 \pm 19.23$ & $260.69 \pm 20.38$ \\
\hline & & & & & $H p^{* 2} H p^{4 I F}$ & $53.22 \pm 12.31^{\mathrm{d}}$ & $97.68 \pm 19.54$ & $159.64 \pm 35.97$ & $193.71 \pm 35.86$ \\
\hline $2-2$ & $84.29 \pm 16.67$ & $116.47 \pm 21.82$ & $169.40 \pm 24.44$ & $200.34 \pm 26.12$ & $H p^{* 2} \mathrm{Hp}^{* 2}$ & $84.29 \pm 16.67$ & $116.47 \pm 21.82$ & $169.40 \pm 24.44$ & $200.34 \pm 26.12$ \\
\hline
\end{tabular}

Data are reported as means \pm SE (standard error of the mean). Values are presented in arbitrary units for DNA damage in comet assay, considering the control group and the different treatments with $\mathrm{H}_{2} \mathrm{O}_{2}$, in the different phenotypes and genotypes. *Significantly different from the $\mathrm{H}_{2} \mathrm{O}_{2}$ groups by the Tukey multiple comparison test** ${ }^{a}$ Significant at $\mathrm{P}<0.05$ by the Fisher test comparing all treatments. ${ }^{\mathrm{b}}$. Significant at $\mathrm{P}<0.05$ by the Fisher comparison test $^{\mathrm{d}}$. Values of $\mu$ (score) are presented in arbitrary units for DNA damage in comet assay.

The variation in DNA damage among the three Hp phenotypes was significant $(\mathrm{P}=$ 0.028 , ANOVA). In the $250 \mu \mathrm{M}$ and $1 \mathrm{mM} \mathrm{H}_{2} \mathrm{O}_{2}$ treatments, greater DNA damage was observed in Hp2-1, while at $2 \mathrm{mM}$, less DNA damage was observed in Hp2-2. The Hp1-1 phenotype had the least DNA damage in the untreated group and in the group treated with $\mathrm{H}_{2} \mathrm{O}_{2}$ at 
$1.0 \mathrm{mM}$, while DNA damage was lower for the Hp2-2 phenotype in the treatments with $\mathrm{H}_{2} \mathrm{O}_{2}$ at $250 \mu \mathrm{M}$ and $2.0 \mathrm{mM}$. The only significant differences were found between the phenotypes Hp1-1 and Hp2-1 ( $\mathrm{P}<0.05$, Fisher multiple comparisons test), which was associated with $\mathrm{Hp} 1 \mathrm{~F}-1 \mathrm{~F}$ and Hp1F-2. In fact, in the untreated Hp1-1 group there was less DNA damage in individuals carrying the $\mathrm{Hp}^{*}{ }^{* I F}$ allele; in the treatments with $\mathrm{H}_{2} \mathrm{O}_{2}$, only homozygous $\mathrm{Hp} 1 \mathrm{~F}-1 \mathrm{~F}$ had less DNA damage. The same results were observed for Hp2-1, as Hp2-1F individuals had less DNA damage than did Hp2-1S individuals.

\section{DISCUSSION}

The $H p^{* 1}$ allele frequency of $41.1 \%$ that we found was similar to those reported from other urban Brazilian populations in São Paulo State (46\%) (Wobeto et al., 2007) and Eurodescendants from Porto Alegre (41.4\%) (Tondo et al., 1963), and the phenotype frequencies were close to those found by Wobeto et al., 2007. The allele frequencies that we observed were similar to those observed for the European population of Australia (Lai et al., 1986) and among Germans (Kruger and Puschel, 1993). Given that the distribution of haptoglobin alleles in our sample reflects the history of the creation of Brazil's new capital in the 1960s, which was formed by migrants from all regions of the country, this can be considered representative of the Brazilian population (Callegari-Jacques et al., 2003).

Haptoglobin acts as an antioxidant by binding hemoglobin, preventing iron-catalyzation of free radicals (Wassel, 2000). The binding of $\mathrm{Hb}$ by $\mathrm{Hp}$ is essential for rapid clearance of $\mathrm{Hb}$ from the plasma, after which the high-affinity $\mathrm{Hp}-\mathrm{Hb}$ complex is metabolized by macrophages (Tseng et al., 2004). Exogenous sources of ROS, such as $\mathrm{H}_{2} \mathrm{O}_{2}$, have been documented as causing ROS-induced damage to cellular macromolecules (DNA, RNA, lipids, and proteins; Franco et al., 2008), and oxidants play an important role in the destabilization of lipid membranes through peroxidation, oxidation and inactivation of proteins, and oxidation of nuclear material (Kirschvink et al., 2008). Sing et al., 1988 developed a simple technique that permits sensitive detection of DNA damage in individual cells. The comet assay has been a useful and effective method for studies of genotoxicology, carcinogenesis and aging. We found that treatments of leukocytes with hydrogen peroxide at concentrations of $250 \mu \mathrm{M}, 1.0 \mathrm{mM}$ and $2.0 \mathrm{mM}$ were effective, causing DNA breaks; this was easily measured with the comet assay.

Guéye et al. (2006) demonstrated that free hemoglobin released by hemolysis is toxic due to oxidative stress and that the protective effect of haptoglobin against this oxidative mechanism is also phenotype dependent. In addition, they showed that subjects with Hp1-1 phenotypes had more protection against oxidative stress than subjects with Hp2-2 phenotypes. Various independent studies have reported the association of Hp phenotypes with increased risk of many chronic degenerative diseases, such as diabetes, retinopathy, nephropathy, and cardiovascular diseases. Moreover, subjects with the Hp2-2 phenotype have an increased risk of developing such diseases compared with those homozygous for the haptoglobin 1 allele, whereas heterozygotes have an intermediate risk (Langlois and Delanghe, 1996; Melamed-Frank et al., 2001; Bernard et al., 2003; Levy, 2003). We also found that there was less DNA damage in the Hp1-1 phenotype than in the other phenotypes. Despite the low frequency of $H p^{* I F}$ in the Brazilian population and our small sample size, we demonstrated that individuals carrying the $H{ }^{*}{ }^{* F}$ allele were more protected against DNA damage than individuals carrying other alleles. 
Various functional properties of $\mathrm{Hp}$ phenotypes have been described as a direct consequence of hemoglobin binding and protection against oxidative stress (Wassel, 2000). Hp1-1 is biologically the most effective in binding free hemoglobin, Hp2-2 is biologically the least active and Hp2-1 is moderately active (Sadrzadeh and Bozorgmehr, 2004). This leads us to expect that people possessing the Hp1-1 phenotype should be more protected against DNA oxidative damage than those possessing other phenotypes. Although we did not evaluate the levels of haptoglobin in the sera, it is well known that the Hp phenotype determines the serum levels of the Hp glycoprotein; people with Hp1-1 have the highest plasma concentrations, those with Hp2-2 the lowest plasma concentrations, and those with Hp2-1 have intermediate concentrations (Sadrzadeh and Bozorgmehr, 2004). On the other hand, there are differences in the binding of haptoglobin types by the CD163 receptor (Carter and Worwood, 2007). We suggest that the product of the $H p^{*}{ }^{*}$ allele could bind more efficiently to either hemoglobin or the CD163 receptor than the products of the other alleles.

\section{CONCLUSIONS}

Phenotype Hp1-1 had greater antioxidant properties than the other phenotypes, which resulted in more efficient protection of leukocytes against oxidative DNA damage. Among $H p^{* I}$ alleles, $H p^{* I F}$ was the most protective.

\section{ACKNOWLEDGMENTS}

Research supported by the University of Brasília (FUNPE and FINATEC) and the National Council of Technological and Scientific Development (CNPq).

\section{REFERENCES}

Bernard D, Christophe A, Delanghe J, Langlois M, et al. (2003). The effect of supplementation with an antioxidant preparation on LDL-oxidation is determined by haptoglobin polymorphism. Redox Rep. 8: 41-46.

Brendler-Schwaab S, Hartmann A, Pfuhler S and Speit G (2005). The in vivo comet assay: use and status in genotoxicity testing. Mutagenesis 20: 245-254.

Callegari-Jacques SM, Grattapaglia D, Salzano FM, Salamoni SP, et al. (2003). Historical genetics: spatiotemporal analysis of the formation of the Brazilian population. Am. J. Hum. Biol. 15: 824-834.

Carter K and Worwood M (2007). Haptoglobin: a review of the major allele frequencies worldwide and their association with diseases. Int. J. Lab. Hematol. 29: 92-110.

Collins AR, Ma AG and Duthie SJ (1995). The kinetics of repair of oxidative DNA damage (strand breaks and oxidised pyrimidines) in human cells. Mutat. Res. 336: 69-77.

Franco R, Schoneveld O, Georgakilas AG and Panayiotidis MI (2008). Oxidative stress, DNA methylation and carcinogenesis. Cancer Lett. 266: 6-11.

Guéye PM, Glasser N, Férard G and Lessinger JM (2006). Influence of human haptoglobin polymorphism on oxidative stress induced by free hemoglobin on red blood cells. Clin. Chem. Lab. Med. 44: 542-547.

Hartmann A, Plappert U, Poetter F and Suter W (2003). Comparative study with the alkaline Comet assay and the chromosome aberration test. Mutat. Res. 536: 27-38.

Jaloszynski P, Kujawski M, Czub-Swierczek M, Markowska J, et al. (1997). Bleomycin-induced DNA damage and its removal in lymphocytes of breast cancer patients studied by comet assay. Mutat. Res. 385: 223-233.

Kirschvink N, de Moffarts B and Lekeux P (2008). The oxidant/antioxidant equilibrium in horses. Vet. J. 177: 178-191. Kruger A and Puschel K (1993). Haptoglobin subtypes in northern Germany (Hamburg). Int. J. Legal Med. 106: 53-54.

Lai LY, Constans J and Archer GT (1986). Isoelectric focusing studies of transferrin and haptoglobin subtypes in an Australian white population. Ann. Hum. Biol. 13: 555-561. 
Langlois MR and Delanghe JR (1996). Biological and clinical significance of haptoglobin polymorphism in humans. Clin. Chem. 42: 1589-1600.

Levy AP (2003). Genetics of diabetic cardiovascular disease: identification of a major susceptibility gene. Acta Diabetol. 40 (Suppl 2): S330-S333.

Melamed-Frank M, Lache O, Enav BI, Szafranek T, et al. (2001). Structure-function analysis of the antioxidant properties of haptoglobin. Blood 98: 3693-3698.

Sadrzadeh SM and Bozorgmehr J (2004). Haptoglobin phenotypes in health and disorders. Am. J. Clin. Pathol. 121 (Suppl): S97-S104.

Silva J, Freitas TRO, Marinho JR, Speit G, et al. (2000). An alkaline single-cell gel electrophoresis (comet) assay for environmental biomonitoring with native rodents. Genet. Mol. Biol. 23: 241-245.

Singh NP, McCoy MT, Tice RR and Schneider EL (1988). A simple technique for quantitation of low levels of DNA damage in individual cells. Exp. Cell Res. 175: 184-191.

Smithies O (1955). Zone electrophoresis in starch gels: group variations in the serum proteins of normal human adults. Biochem. J. 61: 629-641.

Smithies O and Walker NF (1956). Notation for serum-protein groups and the genes controlling their inheritance. Nature 178: 694-695.

Smithies O, Connell GE and Dixon GH (1962). Inheritance of haptoglobin subtypes. Am. J. Hum. Genet. 14: 14-21.

Tondo CV, Mundt C and Salzano FM (1963). Haptoglobin types in Brazilian Negroes. Ann. Hum. Genet. 26: 325-331.

Tseng CF, Lin CC, Huang HY, Liu HC, et al. (2004). Antioxidant role of human haptoglobin. Proteomics 4: 2221-2228.

Wassell J (2000). Haptoglobin: function and polymorphism. Clin. Lab. 46: 547-552.

Wobeto VP, Rosim ET, Melo MB, Calliari LE, et al. (2007). Haptoglobin polymorphism and diabetic retinopathy in Brazilian patients. Diabetes Res. Clin. Pract. 77: 385-388.

Yano A, Yamamoto Y, Miyaishi S and Ishizu H (1998). Haptoglobin genotyping by allele-specific polymerase chain reaction amplification. Acta Med. Okayama 52: 173-181. 